Archive for

Organic Chemistry

Arkivoc 2020, part vii, 145-157

\title{
Oligoyne-bridged boron subphthalocyanine dimers - synthesis and redox properties
}

\section{Anne Ugleholdt Petersen, ${ }^{1}$ Mads Georg Rasmussen, ${ }^{1}$ Maria Cecilia Helleskov Thomsen, Aurore Ceuninck, and Mogens Brøndsted Nielsen*}

Department of Chemistry, University of Copenhagen, Universitetsparken 5, DK-2100 Copenhagen $\varnothing$, Denmark

Email: mbn@chem.ku.dk

${ }^{1}$ These authors contributed equally

Dedicated to Professor Jan Bergman on the occasion of his $80^{\text {th }}$ birthday

Received 06-05-2020

Accepted $07-17-2020$

Published on line $07-24-2020$

\section{Abstract}

Here we present the synthesis and redox properties of a selection of boron subphthalocyanine dimers that are either connected by an oligoyne bridge via the axial boron atoms or via peripheral positions on the cyclic cores. The compounds were prepared by oxidative homodimerization reactions under Glaser-Hay conditions. Moreover, we show that the axial and peripheral terminal alkyne precursors can be subjected to Sonogashira coupling reactions, allowing the introduction of pyridyl end-groups.

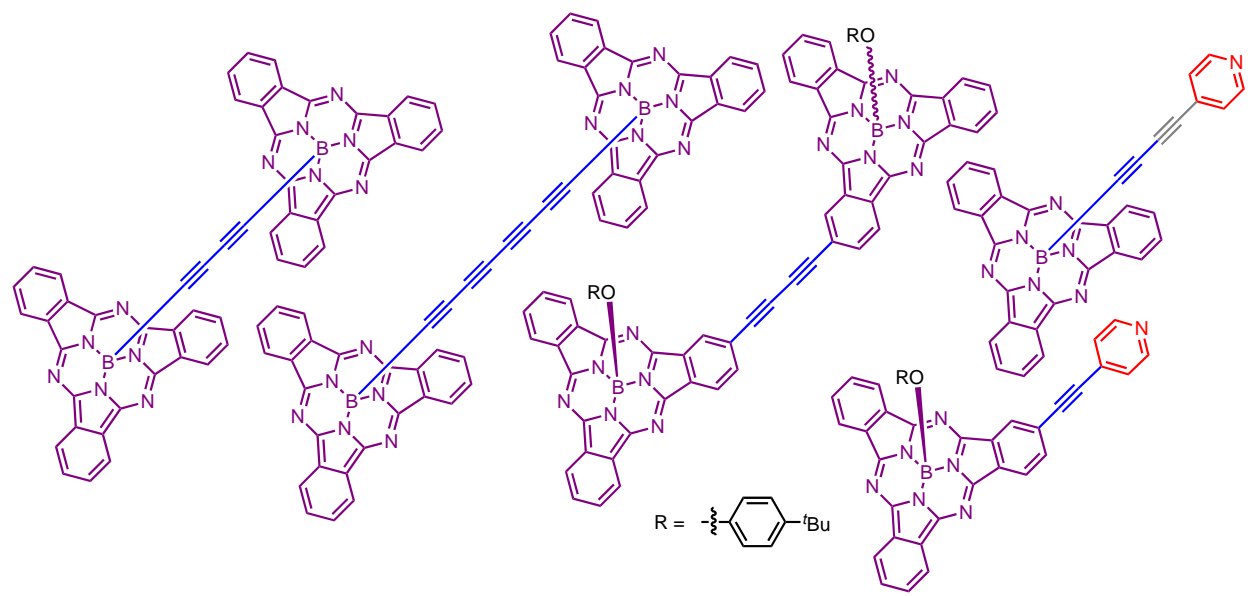

Keywords: Alkynes, Glaser-Hay dimerization, oligoynes, redox centers, subphthalocyanine 


\section{Introduction}

Boron subphthalocyanines are bowl-shaped macrocyclic molecules comprised of three aza-bridged isoindole units and a central boron atom with an axial substituent. ${ }^{1}$ The simplest derivative, SubPc-Cl (Figure 1), having an axial chlorine substituent is prepared in one step from phthalonitrile and boron trichloride. ${ }^{2}$ The axial chloride can easily be replaced by an alkoxy or phenoxy group ${ }^{3}$ as in SubPc-Ar ${ }^{4}$ or by a trimethylsilyl-protected alkyny $^{5}$ as in SubPc-C C $_{2}$ TMS and SubPc- $C_{4}$ TMS. SubPc derivatives are strong chromophores that in the absence of peripheral substituents have an absorption maximum similar to that of SubPc-Ar of $563 \mathrm{~nm}$ and an emission maximum around $573 \mathrm{~nm}$ in chloroform. ${ }^{1,4}$ This class of dyes has in recent years found significant interest for organic light-emitting diodes, photovoltaics and photodynamic therapy applications. ${ }^{6-16}$
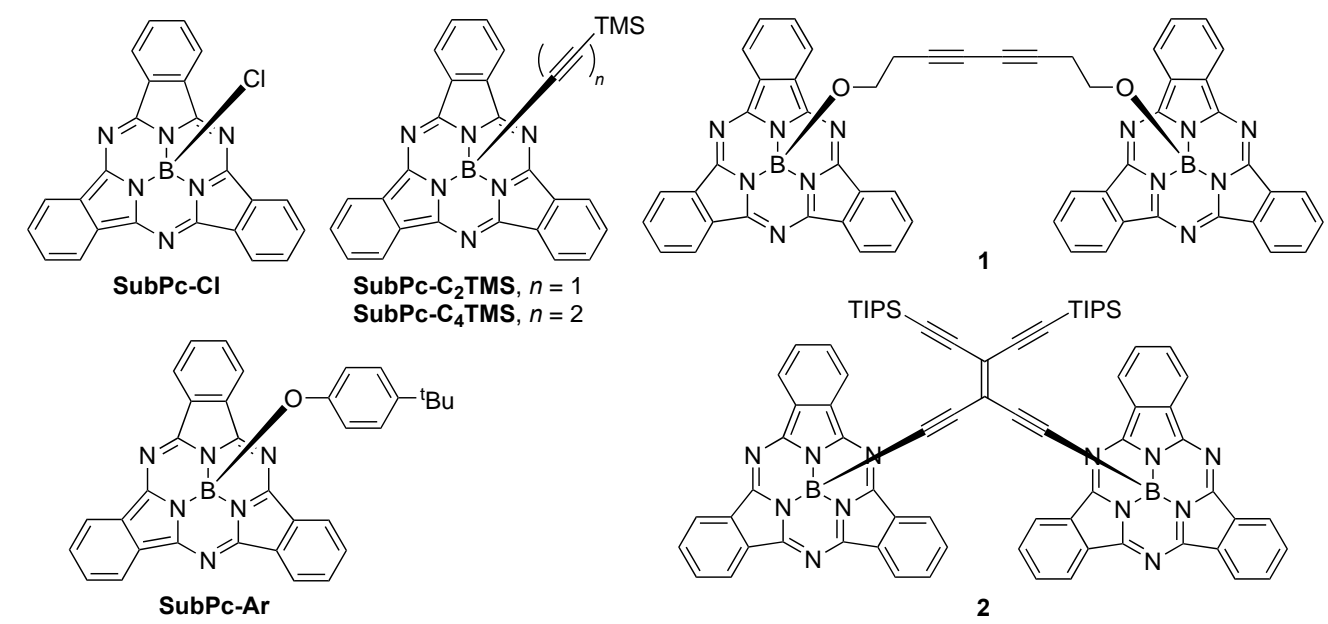

Figure 1. Known boron subphthalocyanine (SubPc) monomers and dimers.

SubPc's are also redox-active compounds. Thus, SubPc-Ar undergoes a reversible one-electron reduction at $-1.56 \mathrm{~V} v \mathrm{Fc} / \mathrm{Fc}^{+}$( $\mathrm{Fc}=$ ferrocene) to a radical anion and a further reduction to a reactive dianion at $-2.05 \mathrm{~V} v s \mathrm{Fc} / \mathrm{Fc}^{+} .4$ It is oxidized to a reactive radical cation at $+0.55 \mathrm{~V} v \mathrm{Fc} / \mathrm{Fc}^{+}$. Linking together two SubPc units by a flexible linker as in compound $\mathbf{1}$ resulted in two-electron reductions and oxidations at potentials similar to those of the monomer, signalling that the two units do not interact. ${ }^{17}$ However, by bridging SubPc units by a tetraethynylethene bridge as in compound $\mathbf{2}$ some changes in redox properties were observed. ${ }^{18}$ The two SubPc units were reduced in a reversible two-electron process at a potential of $-1.57 \mathrm{Vvs} \mathrm{Fc} / \mathrm{Fc}^{+}$; this potential is similar to that of the monomer, but the reduction peak was unusually sharp, which may indicate potential inversion where the monoanion is easier to reduce than the neutral precursor on account of an internal reorganization of the structure. Moreover, the oxidation of the two SubPc units was observed to occur sequentially at $+0.54 \mathrm{~V}$ and $+0.65 \mathrm{vs} \mathrm{Fc} / \mathrm{Fc}^{+}$, which indicates a Coulomb interaction between the two units.

We became interested in elucidating further the redox properties of SubPc dimers and here present the synthesis and properties of dimers 3-5 shown in Figure 2. The SubPc units of dimers $\mathbf{3}$ and $\mathbf{4}$ are connected via butadiynediyl and octatetraynediyl bridges at the axial boron atoms, while the units of dimer $\mathbf{5}$ are connected via a butadiynediyl bridge at periperal positions. Owing to the non-planarity of the SubPc unit, dimer 5 can exist as a meso isomer and a pair of enantiomers. In addition, we present the synthesis of acetylenic SubPc monomers containing a pyridyl end-group at either the axial or peripheral position, which may be employed as ligands for assembling SubPcs in metal complexes (yet to be explored in future work). 


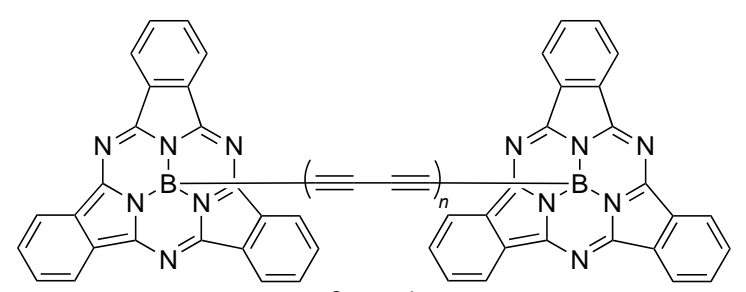

$3, n=1$

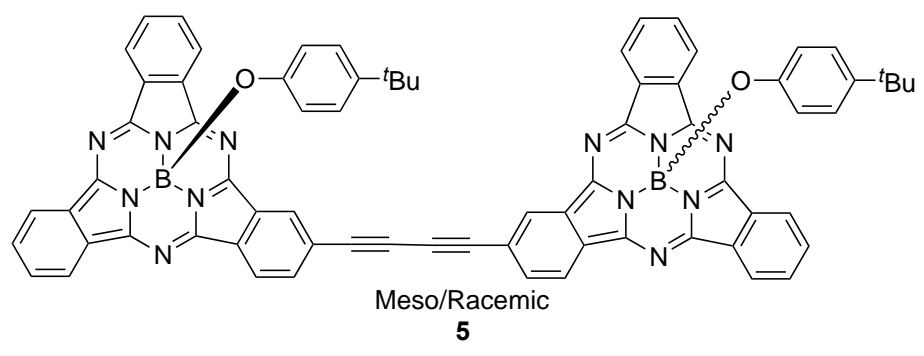

Figure 2. New SubPc dimer target molecules.

\section{Results and Discussion}

Synthesis of dimers 3 and $\mathbf{4}$ proceeds according to Scheme 1. Treating the TMS-protected alkynes SubPc$\mathrm{C}_{2}$ TMS and SubPc- $\mathrm{C}_{4}$ TMS with $\mathrm{AgF}$ and $\mathrm{AcOH}$ gave terminal alkynes that were subjected to oxidative GlaserHay dimerizations using $\mathrm{CuCl}, N, N, N^{\prime}, N^{\prime}$-tetramethylethylenediamine (TMEDA) and oxygen from the air. The dimer 3 was only isolated in a yield $7 \%$ as it had to be subjected to several recrystallizations from a mixture of $\mathrm{CH}_{2} \mathrm{Cl}_{2}$, heptane and toluene before it was obtained in pure form. Purification of the dimer $\mathbf{4}$ was less tedious, and it was obtained pure in a yield of $27 \%$. We managed to grow crystals of 3 from $\mathrm{CH}_{2} \mathrm{Cl}_{2}$, toluene and heptane that were subjected to X-ray crystallographic analysis (Figure 3). The quality of the data is somewhat poor (and there are disordered solvent molecules), but the data are at least good enough to confirm the structure. Structural confirmation of SubPcs often proves challenging when relying only on NMR spectroscopy due to missing carbon resonances ${ }^{5,18,20}$ (as experienced also for the compounds included in this work). In ${ }^{13} \mathrm{C}$ NMR spectroscopic analysis, a dampening of signal intensity (as a result of broadening) for ${ }^{13} \mathrm{C}$ nuclei in vicinity of boron $\left({ }^{1} J\right.$ to $\left.{ }^{4} J\right)$ is observed, related to carbon-boron spin-spin coupling. ${ }^{19}$ Hence inner sp ${ }^{2}$-carbon atoms in the SubPc core as well as sp- and $\mathrm{sp}^{2}$-carbon atoms at the axial substituent suffer from poor signal-to-noise ratios and are often very weak or not visible; ${ }^{5,18,20}$ even with sensitive instrumental parameters.

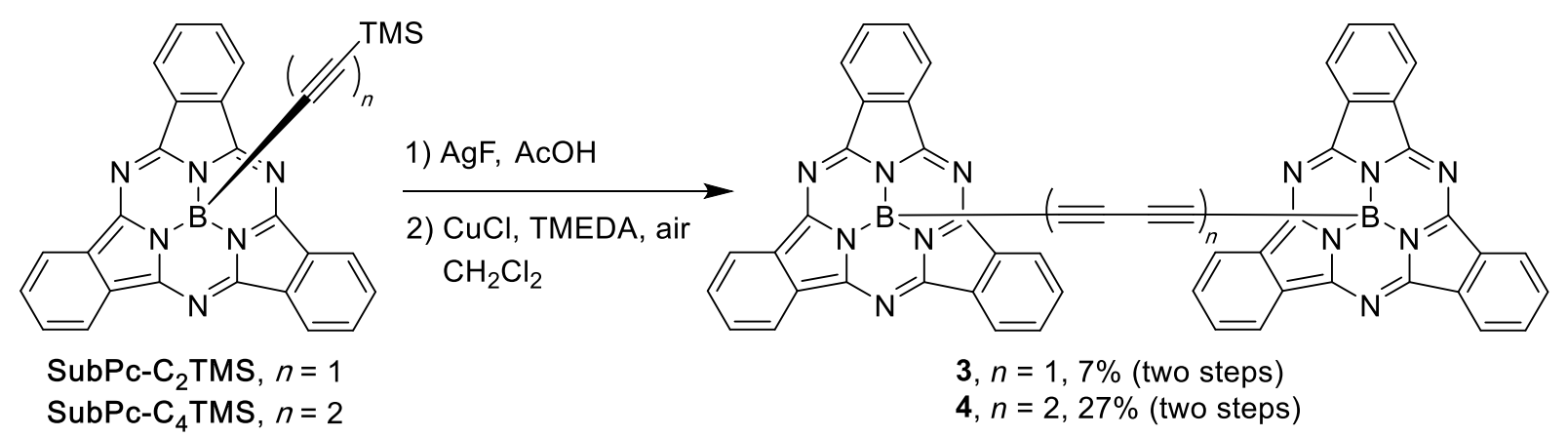

\section{Scheme 1}




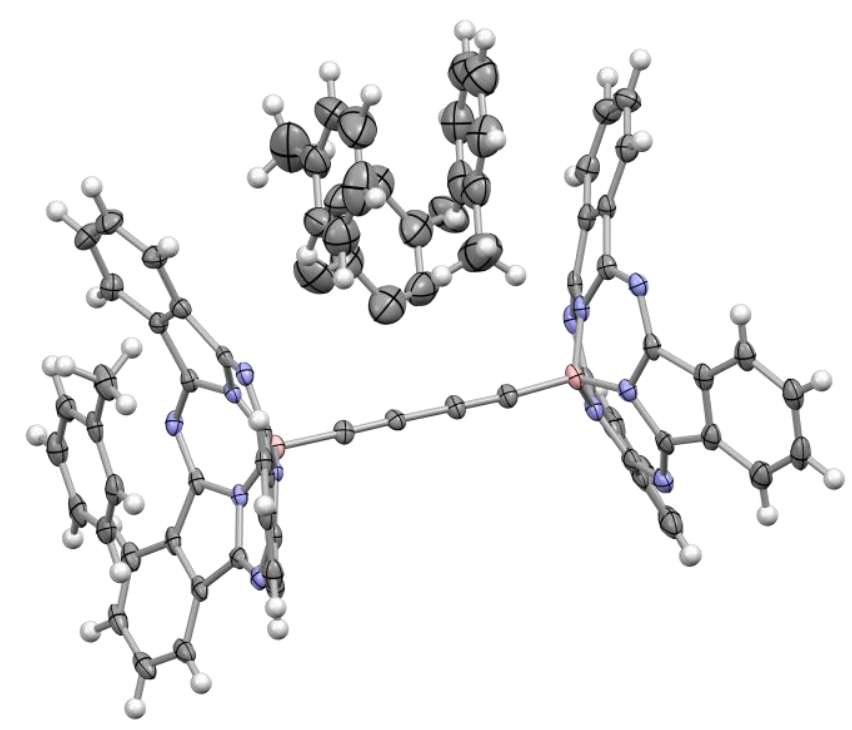

Figure 3. Molecular structure of $\mathbf{3}$ according to X-ray crystallographic analysis; disordered toluene molecules are also shown. CCDC 2006931.

Our next objective was to prepare the SubPc dimer 5 . Treating the known ${ }^{20}$ iodo-functionalized SubPc 6 (racemic mixture) with trimethylsilylacetylene under Sonogashira conditions according to Scheme 2 gave compound 7 (racemic mixture). In this reaction, $\mathrm{AsPh}_{3}$ was used as ligand instead of $\mathrm{PPh}_{3}$ as we have previously $^{17}$ found this replacement advantageously for Sonogashira couplings involving SubPc substrates. Protodesilylation followed by oxidative Glaser-Hay dimerization in $\mathrm{CH}_{2} \mathrm{Cl}_{2}$ gave 5 in a good yield of $66 \%$ when performed at $40{ }^{\circ} \mathrm{C}$ and $52 \%$ when performed at room temperature ( $\mathrm{rt}$ ). This dimer was obtained as a diastereoisomeric mixture of a meso form and pair of enantiomers, which in our hands could not be separated by column chromatography.

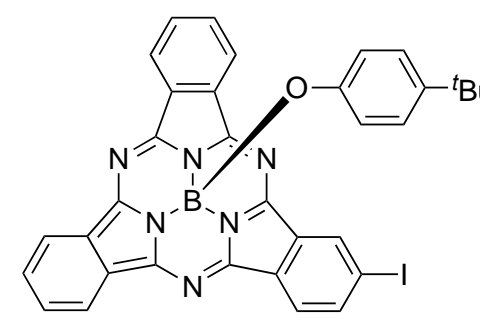

Racemic mixture

6

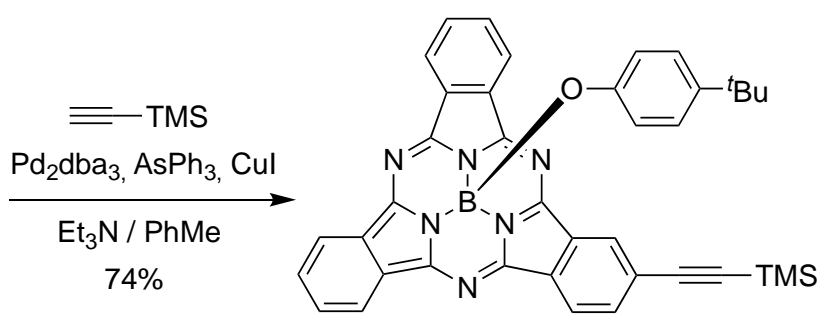

Racemic mixture

7

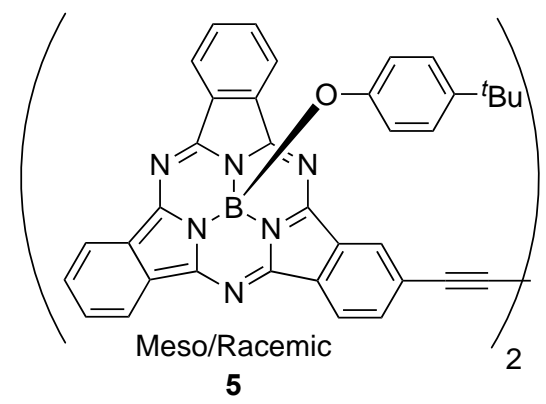

1) $\mathrm{AgF}, \mathrm{AcOH}$

2) $\mathrm{CuCl}, \mathrm{TMEDA}$, air $\mathrm{CH}_{2} \mathrm{Cl}_{2}, 40^{\circ} \mathrm{C}$ (rt)

(two steps)

Scheme 2 
Analysis of the diastereoisomeric mixture of $\mathbf{5}$ by correlation spectroscopy revealed well-defined spin systems allowing assignment of all protons (Figure 4). For the non-substituted peripheral area (Spin systems 1 and 3), multiplet proton signals are observed. However, for the substituted peripheral vicinity (Spin system 2), three paired doublet of doublet signals are observed with internally related coupling constants of $J$ 8.2, 1.4 and $0.8 \mathrm{~Hz}$ (Similar coupling patterns are also observed for the unsymmetrically substituted SubPc derivates 6, 7 and 10). The two diastereoisomers appear to be non-distinguishable by the NMR spectroscopic analysis. We note that there is no reason to believe that the relatively high-yielding synthesis should have provided only one of the diastereoisomers.
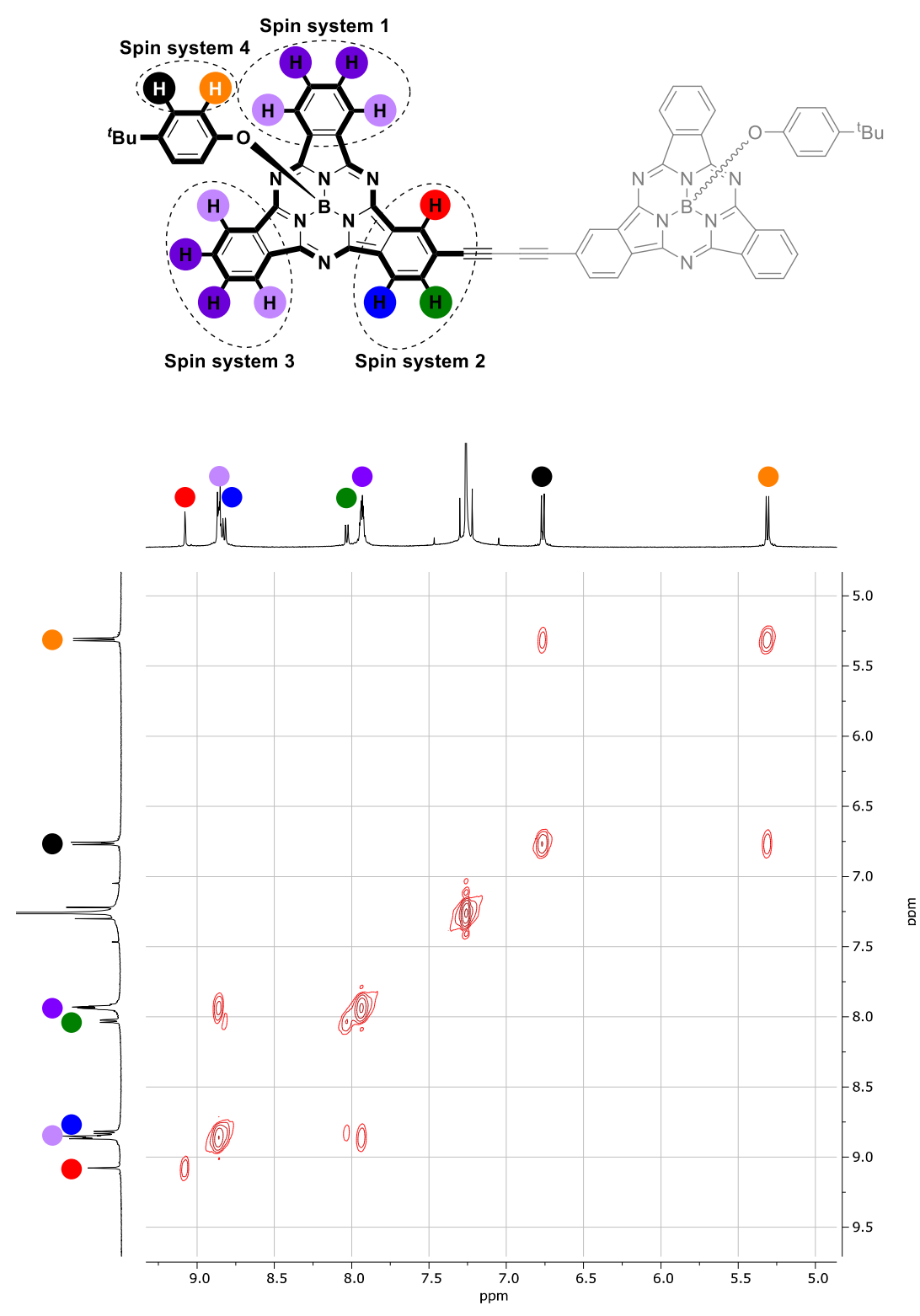

Figure 4. ${ }^{1} \mathrm{H}-{ }^{1} \mathrm{H} \operatorname{COSY}\left(500 \mathrm{MHz}, \mathrm{CDCl}_{3}\right.$ ) spectrum of 5 (aromatic region selected) with assigned protons and spin systems. The tert-Butyl protons resonate at 1.08 ppm (not shown); see SI, Figure S6). 
To explore further the possibility for coupling reactions with the SubPc's containing terminal alkynes,

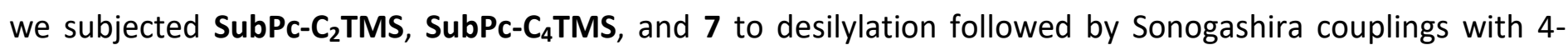
iodopyridine to provide the products 8-10 shown in Scheme 3. In future studies, we will explore the pyridyl groups of these compounds as ligands for metal ions, which can be an alternative way of assembling two SubPc units.

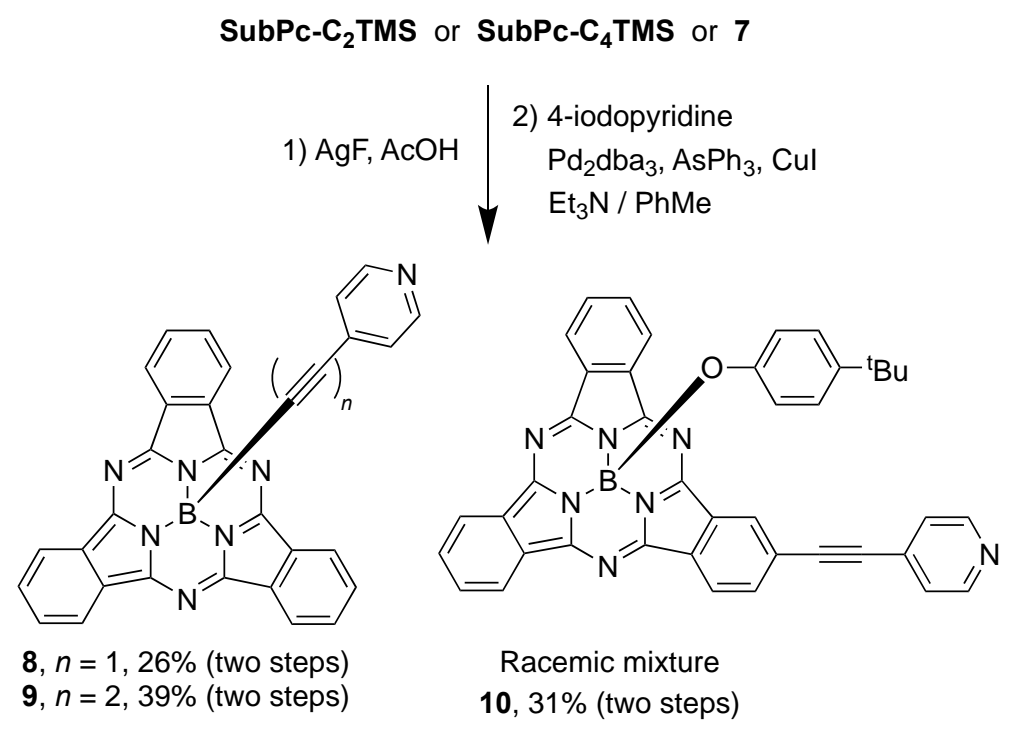

\section{Scheme 3}

The UV-Vis absorption spectra of the three new dimers recorded in toluene are shown in Figure 5. Dimers 3 and 4 have longest-wavelength absorption maxima $\left(\mathrm{S}_{0} \rightarrow \mathrm{S}_{1} \mathrm{Q}\right.$ band $\left.{ }^{1}\right)$ at $568 \mathrm{~nm}\left(\varepsilon=1.36 \times 10^{5} \mathrm{M}^{-1}\right.$ $\left.\mathrm{cm}^{-1}\right)$ and $571 \mathrm{~nm}\left(\varepsilon=1.72 \times 10^{5} \mathrm{M}^{-1} \mathrm{~cm}^{-1}\right)$, respectively, close to those of SubPc-C TMS $\left(569 \mathrm{~nm}\right.$ in $\mathrm{CHCl}_{3} ; \varepsilon=$ $8.91 \times 10^{4} \mathrm{M}^{-1} \mathrm{~cm}^{-1}$ ) and SubPc-C TMS (570 nm in $\left.\mathrm{CHCl}_{3} ; \varepsilon=8.53 \times 10^{4} \mathrm{M}^{-1} \mathrm{~cm}^{-1}\right)$. ${ }^{5}$ The intensities of these absorptions, however, seem to be less than twice those of the corresponding monomers. In contrast, dimer $\mathbf{5}$ exhibits a redshifted longest-wavelength absorption maximum at $593 \mathrm{~nm}\left(\varepsilon=1.74 \times 10^{5} \mathrm{M}^{-1} \mathrm{~cm}^{-1}\right)$, in line with the fact that here a large conjugated $\pi$-system is present.

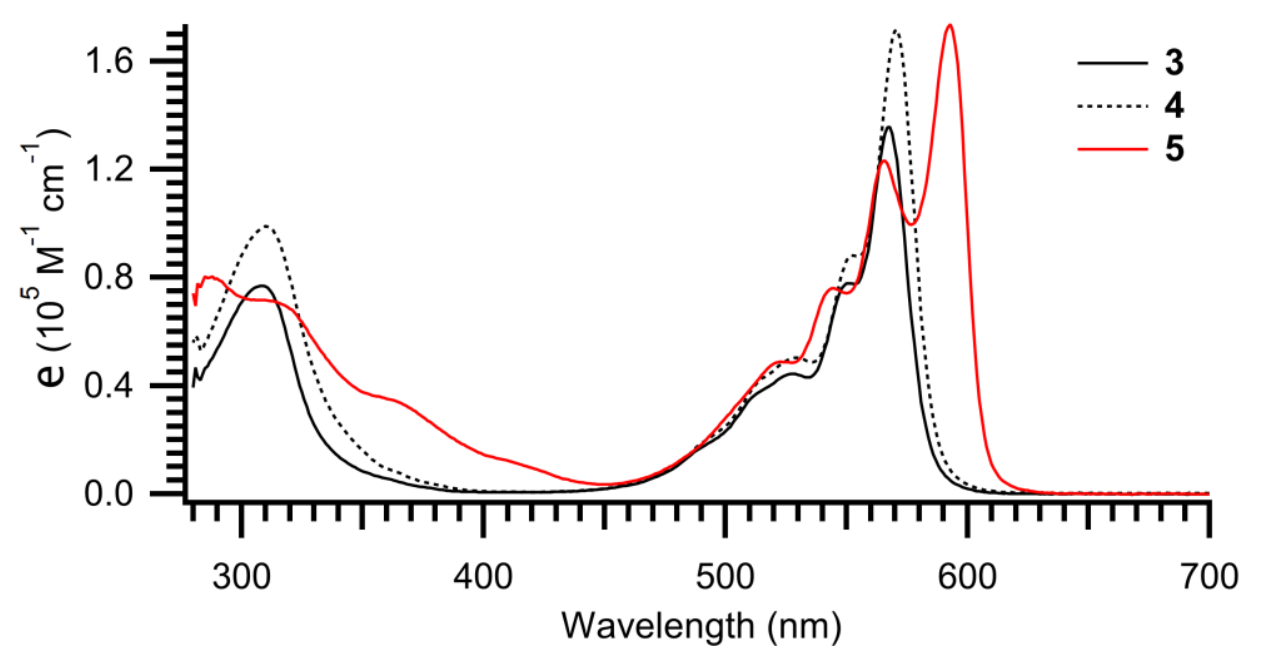

Figure 5. UV-Vis absorption spectra of dimers 3-5 in toluene. 
The cyclic voltammograms (CVs) of dimers 3-5 are shown in Figure 6 together with the cyclic voltammogram of previously studied dimer $2 .^{18}$ The voltammograms were recorded in $\mathrm{CH}_{2} \mathrm{Cl}_{2}$ using $0.1 \mathrm{M}$ $\mathrm{Bu}_{4} \mathrm{NPF}_{6}$ as counter electrolyte, and potentials are referenced vs $\mathrm{Fc} / \mathrm{Fc}^{+}$(the $\mathrm{CV}$ of ferrocene was recorded in a separate experiment). The Supplementary Material shows the corresponding differential pulse voltammograms (DPVs). Interestingly, the two oligoyne-bridged dimers $\mathbf{3}$ and $\mathbf{4}$ were significantly easier to reduce than the tetraethynylethene-bridged dimer 2 . Thus, from the differential pulse voltammograms we observe the first reductions at $-1.51 \vee(3)$ and $-1.49 \vee(4)$, while the first reduction of 2 was previously ${ }^{18}$ reported at $-1.57 \mathrm{~V}$ (all vs $\mathrm{Fc} / \mathrm{Fc}^{+}$). This observation may be explained by the fact that the rigid oligoyne bridges bring the two SubPc units further apart in comparison to the geminally substituted tetraethynylethene bridge (i.e., less Coulomb repulsion). Thus, the boron-boron distance in dimer $\mathbf{3}$ is according to the X-ray crystal structure $6.99 \AA$, while the boron-boron distance in 2 was previously reported to $6.16 \AA$ (based on X-ray crystallographic analysis). Yet, we have recently discovered that radical-stabilizing axial groups (to stabilize unpaired electron located on boron of the SubPc radical anion, while the negative charge is assumed to be delocalized within the macrocycle itself) and conjugated oligoynes render the reduction of SubPcs occur easier. $^{21}$ Thus, the stronger acceptor strengths of $\mathbf{3}$ and $\mathbf{4}$ may also relate to the linearly conjugated bridge separating the two boron centers in $\mathbf{3}$ and $\mathbf{4}$, while the two boron centers are separated by a cross-conjugated bridge in $\mathbf{2}$. In fact, dimers $\mathbf{3}$ and $\mathbf{4}$ are slightly easier to reduce than monomers SubPc- $\mathbf{C}_{\mathbf{2}}$ TMS and SubPc$\mathrm{C}_{4} \mathrm{TMS}$ for which the first reduction occurs at $-1.53 \mathrm{~V}$ vs $\mathrm{Fc} / \mathrm{Fc}^{+} ;{ }^{21}$ this easier reduction may relate to pairing of the unpaired electron on each boron (yet, the potential differences are quite small so one has to be careful in the interpretations). In contrast to $\mathbf{2}$, the oxidations of $\mathbf{3}$ and $\mathbf{4}$ did not occur stepwise, but as a single peak in the DPV at $+0.51 \mathrm{~V}$ (slightly broadened, however) for $\mathbf{3}$ and at $+0.54 \mathrm{~V}$ for $\mathbf{4}$. In comparison, monomers SubPc$\mathrm{C}_{2} \mathrm{TMS}$ and SubPc-C $\mathrm{C}_{4} \mathrm{TMS}$ are oxidized at $0.56 \mathrm{~V}$ and $0.58 \mathrm{~V}$, respectively. ${ }^{21}$ Dimer $\mathbf{5}$ where the cores of the two SubPc units are conjugated showed a reversible first reduction (-1.48 V from the DPV), close to that of dimers 3 and $\mathbf{4}$, and a second quasi-reversible reduction (-1.93 $\vee$ from the DPV). The oxidation of 5 was slightly more difficult than for the other dimers, occurring at $+0.57 \mathrm{~V}$. 


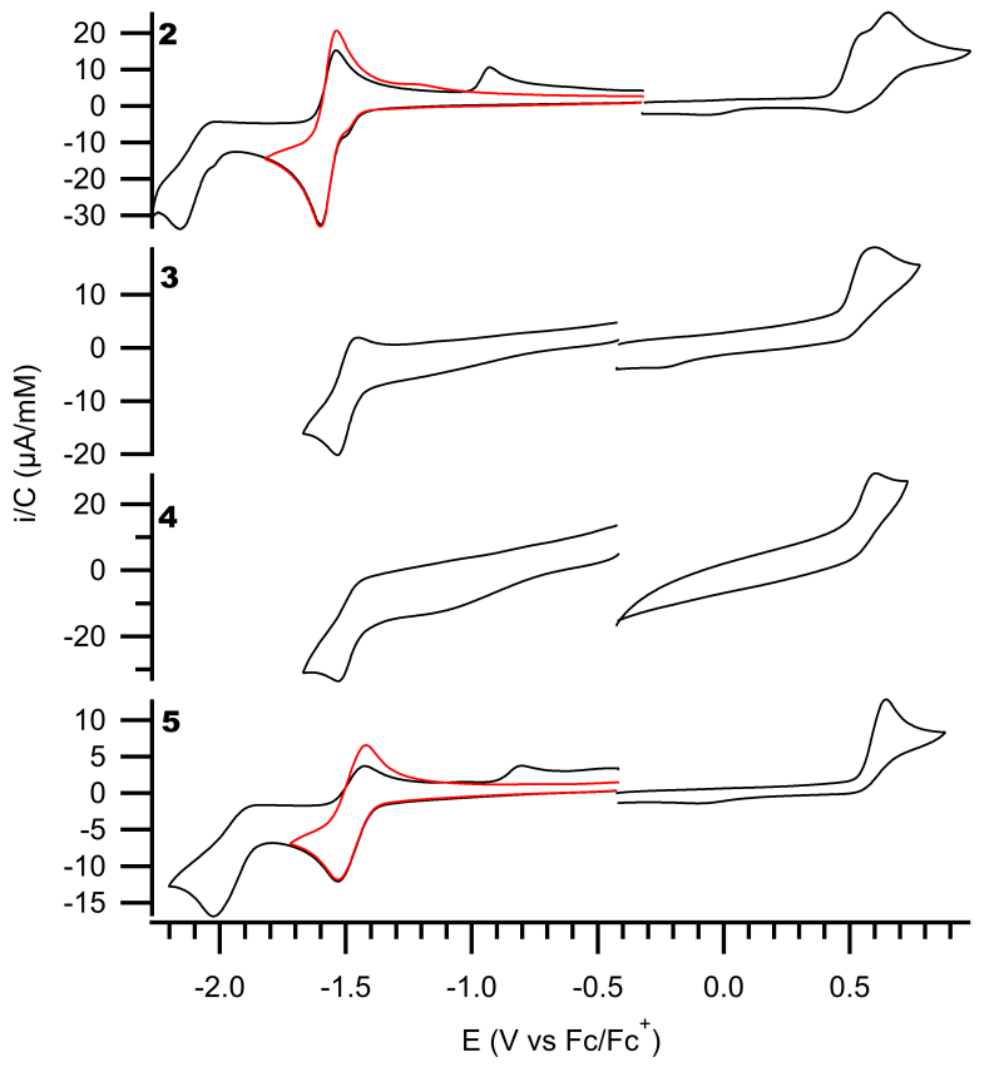

Figure 6. Cyclic voltammograms of dimers 2-5 in $\mathrm{CH}_{2} \mathrm{Cl}_{2}\left(+0.1 \mathrm{M} \mathrm{Bu}_{4} \mathrm{NPF}_{6}\right)$. Compounds 3 and 4 suffered from limited solubilites; hence the voltammograms of these were run at more dilute concentrations.

\section{Conclusions}

In summary, alkynylated SubPc derivatives were subjected to oxidative Glaser-Hay dimerizations, providing a selection of three new SubPc dimers. Dimerization by oligoyne bridges via the axial boron positions has little influence on the photophysical properties (dimers 3 and 4), while dimerization via peripheral positions results in a redshifted longest-wavelength absorption (dimer 5). The two SubPc units of the oligoyne-bridged dimers 3 and $\mathbf{4}$ were easier to reduce than the two units of the previously studied tetraethynylethene-bridged dimer $\mathbf{2}$. This difference may be ascribed to a difference in geometries of these compounds (different degrees of Coulomb repulsions), but probably more likely to a larger degree of stabilization of an unpaired electron on each of the two boron atoms of the dianionic structure when the boron atoms are separated by linearly conjugated oligoyne bridges. To elucidate the subtle interactions that are in play, it could be interesting to subject the dianions to quantum-chemical calculations in the future.

\section{Experimental Section}

General. All reagents and solvents were obtained from commercial suppliers and used as received unless otherwise stated. The following compounds were prepared according to reported literature procedures: SubPc-C $\mathrm{C}_{2}$ TMS, SubPc-C $\mathrm{TMS}^{5}$ and $6^{20}$. Purification by column chromatography was carried out on silica gel 
$\left(\mathrm{SiO}_{2}, 60 \AA\right.$, 40-63 $\left.\mu \mathrm{m}\right)$. Thin-layer chromatography (TLC) was run on commercially available aluminum sheets pre-coated with silica gel and a fluorescence indicator and visualized under UV light (254 or $360 \mathrm{~nm}$ ). NMR spectra were collected on a $500-\mathrm{MHz}$ Bruker instrument with cryoprobe. Chemical shift values $(\delta)$ are quoted in ppm and coupling constants $(\mathrm{J})$ in $\mathrm{Hz} .{ }^{1} \mathrm{H}$ and ${ }^{13} \mathrm{C}$ NMR spectra are referenced to the deuterated solvent peak $\left(\mathrm{CDCl}_{3} \delta_{\mathrm{H}}=7.26 \mathrm{ppm}, \delta_{\mathrm{C}}=77.16 \mathrm{ppm}\right)$. Mass spectrometry (HRMS) was performed using either Electrospray Ionization (ESI) or Matrix Assisted Laser Desorption Ionization (MALDI); FT-ICR = Fourier Transform lon Cyclotron Resonance with dithranol as matrix. UV-Vis absorption measurements were collected on a Varian Cary 50 Bio UV-Visible Spectrometer (cuvette: $1 \mathrm{~cm}$ path length) in neat toluene. Cyclic voltammetry and differential pulse voltammetry were carried out using an Autolab PGSTAT12 instrument with Nova 1.11 software. All samples were analyzed in argon degassed dichloromethane solutions of $0.1 \mathrm{M}$ tetrabutylammonium hexafluorophosphate at scan rates of $100 \mathrm{mV} / \mathrm{s}$. A conventional three-electrode system was used - a glassy carbon disk $(\mathrm{d}=3 \mathrm{~mm})$ as the working electrode, a platinum wire as counter electrode and a silver wire as the reference electrode separated from the bulk solution by a ceramic frit. The potential of the reference electrode was determined versus ferrocene/ferrocenium $\left(\mathrm{Fc}_{\mathrm{f}} / \mathrm{Fc}^{+}\right)$redox system. Melting points are not corrected.

Dimer 3. SubPc- $\mathrm{C}_{2}$ TMS (70 mg, $\left.0.14 \mathrm{mmol}\right)$ was dissolved in a solution of $\mathrm{CH}_{2} \mathrm{Cl}_{2}(9 \mathrm{~mL})$ and $\mathrm{AcOH}(0.6 \mathrm{~mL}, 0.7$ $\mathrm{M}$ in $\mathrm{CH}_{2} \mathrm{Cl}_{2}$ ), and then $\mathrm{AgF}(204 \mathrm{mg}, 1.61 \mathrm{mmol}$ ) was added. The mixture was allowed to stir for $40 \mathrm{~min}$, and then aqueous $\mathrm{HCl}(100 \mathrm{~mL}, 0.1 \mathrm{M})$ was added. The reaction mixture was vigorously stirred and extracted with $\mathrm{CH}_{2} \mathrm{Cl}_{2}(8 \times 50 \mathrm{~mL})$, the combined organic phases was dried over $\mathrm{MgSO}_{4}$ and filtered. The volume was reduced to $50 \mathrm{~mL}$ and transferred to an open flask with $4 \AA$ molecular sieves $(4.1 \mathrm{~g}$ ). Then the catalyst system $\mathrm{CuCl}$ (79 $\mathrm{mg}, 0.80 \mathrm{mmol})$ and TMEDA $(0.32 \mathrm{~mL}, 2.1 \mathrm{mmol})$ was added in $\mathrm{CH}_{2} \mathrm{Cl}_{2}(2 \mathrm{~mL})$. After stirring for $1.5 \mathrm{~h}$, more catalyst was added, $\mathrm{CuCl}(77 \mathrm{mg}, 0.78 \mathrm{mmol})$ and TMEDA $(0.35 \mathrm{~mL}, 2.3 \mathrm{mmol})$ in $\mathrm{CH}_{2} \mathrm{Cl}_{2}(2 \mathrm{~mL})$, and the reaction mixture was allowed to stir for another $2 \mathrm{~h}$. Then a third addition of catalyst, $\mathrm{CuCl}(82 \mathrm{mg}, 0.83 \mathrm{mmol})$ and TMEDA $(0.35 \mathrm{~mL}, 2.3 \mathrm{mmol})$ in $\mathrm{CH}_{2} \mathrm{Cl}_{2}(2 \mathrm{~mL})$, was added, and the mixture was stirred for another $20 \mathrm{~h}$. The reaction mixture was passed through a plug of silica (eluent, toluene to EtOAc) twice. The remains were then recrystallized several times from a mixture of $\mathrm{CH}_{2} \mathrm{Cl}_{2}$, heptane and toluene, until a purple powder of the pure product 3 was obtained ( $4 \mathrm{mg}, 7 \%) . R_{\mathrm{f}}=0.26$ (5\% ethyl acetate/toluene). $\mathrm{Mp}>230{ }^{\circ} \mathrm{C} .{ }^{1} \mathrm{H} \mathrm{NMR}(500 \mathrm{MHz}$, $\left.\mathrm{CDCl}_{3}\right): \delta=8.71(\mathrm{dd}, J 5.9,3.0 \mathrm{~Hz}, 6 \mathrm{H}), 7.81(\mathrm{dd}, J 5.9,3.0 \mathrm{~Hz}, 6 \mathrm{H}) \mathrm{ppm} .{ }^{13} \mathrm{C} \mathrm{NMR}\left(125 \mathrm{MHz}, \mathrm{CDCl}_{3}\right): \delta=150.15$, 130.80, 129.74, 122.12 ppm (2 signals missing). HRMS (MALDI +ve FT-ICR, dithranol) calcd for $\mathrm{C}_{52} \mathrm{H}_{24} \mathrm{~B}_{2} \mathrm{~N}_{12}$ $\left[(\mathrm{M})^{++}\right]: \quad \mathrm{m} / \mathrm{z}=836.25001 / 837.24638 / 838.24275 / 839.24611 ; \quad$ exp: $\mathrm{m} / \mathrm{z}=$ 836.24807/837.24448/838.24068/839.24846; $\quad \mathrm{C}_{52} \mathrm{H}_{25} \mathrm{~B}_{2} \mathrm{~N}_{12} \quad\left[(\mathrm{M}+\mathrm{H})^{+}\right]: \quad \mathrm{m} / \mathrm{z}=\quad$ 837.25784/ 838.25421/839.25058/840.25393; exp: $m / z=837.25612 / 838.25205 / 839.25590 / 840.25193$.

Dimer 4. To a solution of SubPc- $\mathrm{C}_{4} \mathrm{TMS}(108 \mathrm{mg}, 0.21 \mathrm{mmol})$ in $\mathrm{CH}_{2} \mathrm{Cl}_{2}(10 \mathrm{~mL})$ were added AcOH $(1 \mathrm{~mL}, 0.7 \mathrm{M}$ in $\mathrm{CH}_{2} \mathrm{Cl}_{2}$ ) and $\mathrm{AgF}(267 \mathrm{mg}, 2.10 \mathrm{mmol})$, and the reaction mixture was allowed to stir for $30 \mathrm{~min}$. Then aqueous $\mathrm{HCl}(30 \mathrm{~mL}, 1 \mathrm{M})$ was added, and the biphasic mixture was allowed to stir for another $30 \mathrm{~min}$. The phases were separated, and the aqueous phase was extracted with $\mathrm{CH}_{2} \mathrm{Cl}_{2}(4 \times 20 \mathrm{~mL})$. The combined organic phases were dried over $\mathrm{MgSO}_{4}$ and filtered, after which the solvent was reduced to $50 \mathrm{~mL}$. Next, TMEDA (0.3 $\mathrm{mL}$ ) and $\mathrm{CuCl}(62 \mathrm{mg}, 0.63 \mathrm{mmol}$ ) were added, and the reaction mixture was allowed to stirr for $21 \mathrm{~h}$ in an open flask. After the reaction was done, more $\mathrm{CH}_{2} \mathrm{Cl}_{2}$ was added to fully dissolve the product, which was run through a plug of silica (gradient eluent, $50 \% \mathrm{CH}_{2} \mathrm{Cl}_{2}$ /toluene to toluene to $50 \% \mathrm{EtOAc/toluene).} \mathrm{After}$ removing the solvent under reduced pressure, the material was recrystallized from $\mathrm{CH}_{2} \mathrm{Cl}_{2} / n$-heptane to give the product 4 as a purple solid $(25 \mathrm{mg}, 27 \%) . R_{\mathrm{f}}=0.26$ (5\% EtOAc/toluene). M.p. $>230{ }^{\circ} \mathrm{C} .{ }^{1} \mathrm{H} \mathrm{NMR}(500 \mathrm{MHz}$, 
$\left.\mathrm{CDCl}_{3}\right): \delta=8.80(\mathrm{dd}, J 5.9,3.0 \mathrm{~Hz}, 12 \mathrm{H}), 7.87(\mathrm{dd}, J 5.9,3.0 \mathrm{~Hz}, 12 \mathrm{H}) \mathrm{ppm} .{ }^{13} \mathrm{C} \mathrm{NMR}\left(125 \mathrm{MHz}, \mathrm{CDCl}_{3}\right): \delta=$ $150.35,130.90,129.96,122.28$ ppm (4 signals missing). HRMS (MALDI +ve FT-ICR, dithranol) calcd. for $\mathrm{C}_{56} \mathrm{H}_{24} \mathrm{~B}_{2} \mathrm{~N}_{12} \quad\left[(\mathrm{M})^{++}\right]: \quad m / z=885.24638 / 886.24275 / 887.24611, \quad$ exp: $m / z=885.24538 /$ 886.25325/887.24960; $\left.\quad \mathrm{C}_{56} \mathrm{H}_{25} \mathrm{~B}_{2} \mathrm{~N}_{12} \quad[(\mathrm{M})+\mathrm{H})^{+}\right]: \quad m / z=886.25421 / 887.25058 / 888.25393, \quad \exp : \quad m / z=$ $886.25325 / 887.24960 / 888.25293$.

Compound 7. An argon purged solution of $\mathrm{Et}_{3} \mathrm{~N}$ in toluene $1: 3(12 \mathrm{~mL})$ was added to an argon purged reaction flask containing 6 (142 mg, $0.212 \mathrm{mmol}$ ), $\mathrm{Pd}_{2} \mathrm{dba}_{3}$ (39 mg, $0.43 \mu \mathrm{mol}$ ), Cul (8 mg, $0.04 \mu \mathrm{mol}$ ), and AsPh $\mathrm{As}_{3}(104$ $\mathrm{mg}, 0.340 \mathrm{mmol})$. The flask was charged with trimethylsilylacetylene $(1.17 \mathrm{~mL}, 8.47 \mathrm{mmol})$ and purged with argon for 2 min under sonication. The reaction mixture was stirred for $48 \mathrm{~h}$, after which it was passed through a small plug of $\mathrm{SiO}_{2}$ (eluent, 20\% EtOAc/toluene), concentrated in vacuo and subjected to flash column chromatography (eluent, 20\% EtOAc/heptane), which yielded the product 7 as a pink solid (101 $\mathrm{mg}, 74 \%) . \mathrm{R}_{f}=$ 0.33 (20\% EtOAc/heptanes). Mp $185-186{ }^{\circ} \mathrm{C} .{ }^{1} \mathrm{H}$ NMR $\left(500 \mathrm{MHz}, \mathrm{CDCl}_{3}\right): \delta=8.96$ (dd, J $\left.1.4 \mathrm{~Hz}, 0.8 \mathrm{~Hz}, 1 \mathrm{H}\right)$, $8.87-8.80(\mathrm{~m}, 4 \mathrm{H}), 8.75(\mathrm{dd}, J 8.2 \mathrm{~Hz}, 0.8 \mathrm{~Hz}, 1 \mathrm{H}), 7.94(\mathrm{dd}, J 8.2 \mathrm{~Hz}, 1.4 \mathrm{~Hz}, 1 \mathrm{H}), 7.92-7.89(\mathrm{~m}, 4 \mathrm{H}), 6.74(\mathrm{~d}, J$ $8.8 \mathrm{~Hz}, 2 \mathrm{H}), 5.29(\mathrm{~d}, J 8.8 \mathrm{~Hz}, 2 \mathrm{H}), 1.07(\mathrm{~s}, 9 \mathrm{H}), 0.33(\mathrm{~s}, 9 \mathrm{H}) \mathrm{ppm} .{ }^{13} \mathrm{C} \mathrm{NMR}\left(126 \mathrm{MHz}, \mathrm{CDCl}_{3}\right): \delta=152.26,151.76$, $150.73,150.12,143.78,132.91,131.28,131.16,131.13,130.81,130.16,130.15,130.07,129.99,126.18$, 125.83, 124.65, 122.43, 122.37, 122.35, 122.07, 117.83, 105.00, 97.42, 77.16, 33.96, 31.45, 0.09 ppm (5 signals missing). HRMS (MALDI +ve FT-ICR, dithranol) $\mathrm{C}_{39} \mathrm{H}_{34} \mathrm{BN}_{6} \mathrm{OSi}\left[(\mathrm{M})+\mathrm{H}^{+}\right]: \mathrm{m} / z=641.26509, \exp \mathrm{m} / z=641.26584$.

Dimer 5. Method A. A solution of 7 (31 mg, $0.048 \mathrm{mmol}$ ) in $\mathrm{CH}_{2} \mathrm{Cl}_{2} / \mathrm{MeCN}$ 3:1 (4 mL) was charged with $\mathrm{AgF}$ (38 $\mathrm{mg}, 0.30 \mathrm{mmol})$ and $\mathrm{ACOH}$ in $\mathrm{CH}_{2} \mathrm{Cl}_{2}(0.5 \mathrm{~mL}, 0.7 \mathrm{M})$ and let to stir for $30 \mathrm{~min}$. The reaction mixture was poured into aqueous $\mathrm{HCl}(50 \mathrm{~mL}, 0.05 \mathrm{M})$ and extracted with $\mathrm{CH}_{2} \mathrm{Cl}_{2},(3 \times 50 \mathrm{~mL})$, dried over $\mathrm{MgSO}_{4}$, filtered on a sintered funnel (pore 3 ) and concentrated in vacuo to a volume of $10 \mathrm{~mL}$. The concentrate was transferred to a smaller reaction flask, and $\mathrm{CuCl}(18.8 \mathrm{mg}, 0.190 \mathrm{mmol})$ and TMEDA $(0.06 \mathrm{~mL}, 0.40 \mathrm{mmol})$ were added. The reaction mixture was vigorously stirred in open flask at $40{ }^{\circ} \mathrm{C}$ for $45 \mathrm{~min}$, filtered through a small plug $\mathrm{SiO}_{2}$, (eluent, EtOAc), concentrated in vacuo, and subjected to flash column chromatography (eluent, $30 \%$ EtOAc/heptanes), which yielded a diastereomeric mixture of 5 as a purple solid (17 $\mathrm{mg}, 66 \%)$. Method B: A solution of 7 (32 mg, $0.050 \mathrm{mmol}$ ) in $\mathrm{CH}_{2} \mathrm{Cl}_{2} / \mathrm{MeCN} \mathrm{3:1} \mathrm{(4} \mathrm{mL)} \mathrm{was} \mathrm{charged} \mathrm{with} \mathrm{AgF} \mathrm{(32} \mathrm{mg,} 0.25 \mathrm{mmol}$ ) and $\mathrm{AcOH}$ in $\mathrm{CH}_{2} \mathrm{Cl}_{2}(0.5 \mathrm{~mL}, 0.7 \mathrm{M})$ and let to stir for $30 \mathrm{~min}$. The reaction mixture was poured into aqueous $\mathrm{HCl}$ $(50 \mathrm{~mL}, 0.05 \mathrm{M})$ and extracted with $\mathrm{CH}_{2} \mathrm{Cl}_{2}(3 \times 50 \mathrm{~mL})$, dried over $\mathrm{MgSO}_{4}$, filtered on a sintered funnel (pore 3) and concentrated in vacuo to a volume of $10 \mathrm{~mL}$. The concentrate was transferred to a smaller reaction flask

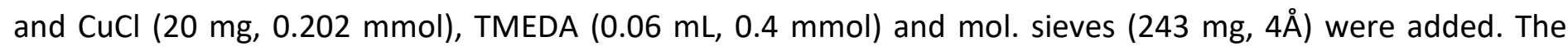
reaction mixture was vigorously stirred in open flask at rt for $45 \mathrm{~min}$, filtered through a small plug $\mathrm{SiO}_{2}$, eluted with EtOAc, dried over $\mathrm{MgSO}_{4}$, concentrated in vacuo and subjected to flash column chromatography $\left(\mathrm{SiO}_{2}\right.$, $30 \%$ EtOAc/heptanes), which yielded a diastereomeric mixture of 5 as a purple solid (14.6 $\mathrm{mg}, 52 \%) . \mathrm{R}_{f}=0.19$ (30\% EtOAc/heptanes). M.p. $>230{ }^{\circ} \mathrm{C} .{ }^{1} \mathrm{H}$ NMR $\left(500 \mathrm{MHz}, \mathrm{CDCl}_{3}\right): \delta=9.08$ (dd, $\left.J 1.4 \mathrm{~Hz}, 0.8 \mathrm{~Hz}, 2 \mathrm{H}\right), 8.88-8.84$ $(\mathrm{m}, 8 \mathrm{H}), 8.82(\mathrm{dd}, J 8.2 \mathrm{~Hz}, 0.8 \mathrm{~Hz}, 2 \mathrm{H}), 8.03(\mathrm{dd}, \mathrm{J} 8.2 \mathrm{~Hz}, 1.4 \mathrm{~Hz}, 2 \mathrm{H}), 7.95-7.90(\mathrm{~m}, 8 \mathrm{H}), 6.76(\mathrm{~d}, J 8.8,4 \mathrm{H})$, $5.31(\mathrm{~d}, J 8.8 \mathrm{~Hz}, 4 \mathrm{H}), 1.08(\mathrm{~s}, 18 \mathrm{H}) \mathrm{ppm} .{ }^{13} \mathrm{C} \mathrm{NMR}\left(126 \mathrm{MHz}, \mathrm{CDCl}_{3}\right): \delta=152.75,152.67,151.95,151.83$, $150.29,150.10,143.86,133.08,131.39,131.17,131.15,130.72,130.34,130.32,130.19,126.99,125.88$, $122.89,122.51,122.45,122.41,122.37,117.85,83.07,76.48,33.97,31.46$ ppm. HRMS (MALDI+ FT-ICR, dithranol) calcd. for $\mathrm{C}_{72} \mathrm{H}_{49} \mathrm{~B}_{2} \mathrm{~N}_{12} \mathrm{O}_{2}\left[\mathrm{M}+\mathrm{H}^{+}\right]: m / z=1135.42821$, exp: $m / z=1135.42805$.

Compound 8. SubPc- $\mathrm{C}_{2}$ TMS (151 mg, $0.305 \mathrm{mmol}$ ) was dissolved in $\mathrm{CH}_{2} \mathrm{Cl}_{2}(15 \mathrm{~mL}$ ) by sonicating for $5 \mathrm{~min}$. AcOH (1 mL, $0.7 \mathrm{M}$ in $\mathrm{CH}_{2} \mathrm{Cl}_{2}$ ), MeCN $(4 \mathrm{~mL})$, and AgF (427 mg, $3.36 \mathrm{mmol}$ ) were added to the solution. After 
being stirred for $30 \mathrm{~min}$, the mixture was subjected to an aqueous workup with $\mathrm{HCl}(200 \mathrm{~mL}, 0.05 \mathrm{M})$. The water phase was extracted with $\mathrm{CH}_{2} \mathrm{Cl}_{2}(10 \times 50 \mathrm{~mL})$ until the extracts were nearly colorless. The combined organic phase was dried over $\mathrm{MgSO}_{4}$, concentrated in vacuo until some solvent still remained. Then toluene $(20 \mathrm{~mL})$ and $\mathrm{Et}_{3} \mathrm{~N}(6 \mathrm{~mL})$ were added to the solution, and the mixture was purged with argon under sonication for $20 \mathrm{~min}$. Then 4-iodopyridine (195 mg, $914 \mu \mathrm{mol}), \mathrm{Pd}_{2}(\mathrm{dba})_{3}(61 \mathrm{mg}, 0.067 \mathrm{mmol}), \mathrm{AsPh}_{3}$ (196 mg, 0.64 $\mathrm{mmol}$ ), and Cul (51 $\mathrm{mg}, 0.27 \mathrm{mmol}$ ) were added to the solution. After stirring for $19 \mathrm{~h}$ under argon, the reaction mixture was passed through a short plug of silica (eluent, 50\% EtOAc/toluene). The remains were then subjected to flash column chromatography $\left(\mathrm{SiO}_{2}, 20: 80 \mathrm{EtOAc} /\right.$ toluene), giving the product 8 (40 $\mathrm{mg}$, $26 \%)$ as a purple solid. $R_{\mathrm{f}}=0.28\left(20 \%\right.$ EtOAc/heptane). M.p. $>260{ }^{\circ} \mathrm{C} .{ }^{1} \mathrm{H} \mathrm{NMR}\left(\mathrm{CDCl}_{3}, 500 \mathrm{MHz}\right): \delta=8.88(\mathrm{dd}, \mathrm{J}$ 5.9, 3.0 Hz, 6H), 8.20 (dd, J 4.5, $1.6 \mathrm{~Hz}, 2 \mathrm{H}), 7.92(\mathrm{dd}, J 5.9,3.0 \mathrm{~Hz}, 6 \mathrm{H}), 6.61(\mathrm{~d}, J 4.5,1.6 \mathrm{~Hz}, 2 \mathrm{H}) \mathrm{ppm} .{ }^{13} \mathrm{C} \mathrm{NMR}$ $\left(\mathrm{CDCl}_{3}, 126 \mathrm{MHz}\right): \delta=150.60,131.02,129.97,125.60,122.32 \mathrm{ppm}$ (4 signals missing). HRMS (ESP) calcd for $\mathrm{C}_{31} \mathrm{H}_{17} \mathrm{BN}_{7}^{+}\left[\mathrm{M}+\mathrm{H}^{+}\right]: m / z=497.16693 / 498.16330 / 499.16666, \exp \mathrm{m} / z=497.16626 / 498.16259 / 499.16597$.

Compound 9. SubPc- $\mathrm{C}_{4} \mathrm{TMS}\left(83.3 \mathrm{mg}, 0.166 \mathrm{mmol}\right.$ ) was dissolved in $\mathrm{CH}_{2} \mathrm{Cl}_{2}(5 \mathrm{~mL})$ by sonication for $8 \mathrm{~min}$. Subsequently $\mathrm{AcOH}\left(0.5 \mathrm{~mL}, 0.7 \mathrm{M}\right.$ in $\mathrm{CH}_{2} \mathrm{Cl}_{2}$ ), $\mathrm{MeCN}(2 \mathrm{~mL})$, and $\mathrm{AgF}$ (213 mg, $1.68 \mathrm{mmol}$ ) were added to the solution. After being stirred for $1 \mathrm{~h}$, the solution was subjected to an aqueous workup with $\mathrm{HCl}(150 \mathrm{~mL}, 0.05$ M). The water phase was extracted several times with $\mathrm{CH}_{2} \mathrm{Cl}_{2}(6 \times 50 \mathrm{~mL})$. The combined organic extracts was dried over $\mathrm{MgSO}_{4}$ and concentrated until some $\mathrm{CH}_{2} \mathrm{Cl}_{2}$ was still present. Then toluene (20 $\mathrm{mL}$ ) was added, and the volume was reduced to $10 \mathrm{~mL}$ in vacuo. Then $\mathrm{Et}_{3} \mathrm{~N}(3 \mathrm{~mL})$ was added to the solution, and the mixture was purged with argon while being sonicated for $20 \mathrm{~min}$. Next 4-iodopyridine (97.8 $\mathrm{mg}, 0.498 \mathrm{mmol}), \mathrm{Pd}_{2}\left(\mathrm{dba}_{3}(31\right.$ $\mathrm{mg}, 0.034 \mathrm{~mol}), \mathrm{AsPh}_{3}(97 \mathrm{mg}, 0.32 \mathrm{~mol})$, and Cul $(26 \mathrm{mg}, 0.14 \mathrm{mmol}$ ) were added to the solution. After stirring for $19 \mathrm{~h}$ under argon, the reaction mixture was passed through a short plug of silica (eluent, 50\% EtOAc/toluene). The residue was then subjected to flash column chromatography (eluent, $20 \%$ EtOAc/toluene), giving the product 9 (34 mg, 39\%) as a purple solid. $R_{\mathrm{f}}=0.22$ (20\% EtOAc/Toluene). M.p. $>260$ ${ }^{\circ} \mathrm{C} .{ }^{1} \mathrm{H} \mathrm{NMR}\left(\mathrm{CDCl}_{3}, 500 \mathrm{MHz}\right): \delta=8.87(\mathrm{dd}, J 5.9,3.0 \mathrm{~Hz}, 6 \mathrm{H}), 8.40(\mathrm{br} \mathrm{s}, 2 \mathrm{H}), 7.91(\mathrm{dd}, J 5.9,3.0 \mathrm{~Hz}, 6 \mathrm{H}), 6.97$ (apparent d, J $4.9 \mathrm{HH}) \mathrm{ppm} .{ }^{13} \mathrm{C} \mathrm{NMR}\left(\mathrm{CDCl}_{3}, 126 \mathrm{MHz}\right): \delta=150.49,149.71,130.99,130.02,129.76122 .33$, 77.91, 72.30 ppm (3 signals missing). HRMS (ESP) calcd. for $\mathrm{C}_{33} \mathrm{H}_{17} \mathrm{BN}_{7}^{+} \quad\left[\mathrm{M}+\mathrm{H}^{+}\right]: \mathrm{m} / z=$ 521.16693/522.16330/523.16666, exp: $m / z=521.16564 / 522.16192 / 523.16529$.

Compound 10. A suspension of $7(48 \mathrm{mg}, 0.075 \mathrm{mmol})$ and $\mathrm{CH}_{2} \mathrm{Cl}_{2}(10 \mathrm{~mL})$ was sonicated for $10 \mathrm{~min}$ under argon. Then $\mathrm{AcOH}\left(1 \mathrm{~mL}, 0.7 \mathrm{M}\right.$ in $\left.\mathrm{CH}_{2} \mathrm{Cl}_{2}\right)$ and $\mathrm{AgF}(76.3 \mathrm{mg}, 0.60 \mathrm{mmol}$ ) were added to the mixture, which then was stirred for $1.5 \mathrm{~h}$ at ambient temperature under argon. Then a further portion of $\mathrm{AgF}(28.9 \mathrm{mg}, 0.23$ $\mathrm{mmol}$ ) was added due to the presence of starting material, determined by TLC (eluent, 20\% EtOAc/Heptane). After $1 \mathrm{~h}$ of further stirring, no more starting material could be observed on TLC. The reaction was stopped by addition of aqueous $\mathrm{HCl}(100 \mathrm{~mL}, 0.1 \mathrm{M})$; the mixture was transferred to a separation funnel with $\mathrm{CH}_{2} \mathrm{Cl}_{2}(50$ $\mathrm{mL})$. The biphasic mixture was separated and the aqueous phase was extracted with $\mathrm{CH}_{2} \mathrm{Cl}_{2}(6 \times 50 \mathrm{~mL})$. The combined organic phases were dried over $\mathrm{MgSO}_{4}$ and the drying agent was filtered off. Toluene $(40 \mathrm{~mL}) \mathrm{was}$ added to the solution and $\mathrm{CH}_{2} \mathrm{Cl}_{2}$ was removed under reduced pressure to leave the deprotected alkyne in a toluene solution. Next 4-lodopyridine $(65 \mathrm{mg}, 0.32 \mathrm{mmol})$, and $\mathrm{Et}_{3} \mathrm{~N}(5 \mathrm{~mL})$ were added to the solution, which then was purged with argon. Subsequently $\mathrm{Pd}_{2} \mathrm{dba}_{3}(11.6 \mathrm{mg}, 0.012 \mathrm{mmol}), \mathrm{Cul}(2.2 \mathrm{mg}, 9 \mu \mathrm{mol})$, and $\mathrm{AsPh}_{3}$ (20.2 $\mathrm{mg}, 0.064 \mathrm{mmol})$ were added. The reaction mixture was stirred under argon for 15 hours (TLC eluent: $50 \%$ EtOAc/Heptane). The reaction was quenched with water $(100 \mathrm{~mL})$. The phases were separated, and the water phase was extracted with toluene $(4 \times 40 \mathrm{~mL})$. The combined organic phases were dried over $\mathrm{MgSO}_{4}$, filtered, and concentrated in vacuo. The crude product was purified by flash column chromatography (gradient 
elution, 35-50\% EtOAc/Heptane), then a second purification by flash column chromatography (eluent, $45 \%$ EtOAc/Heptane) to give 10 as a purple solid (31\% yield). $R_{\mathrm{f}}=0.30$ (45\% EtOAc/Heptane). M.p. $=224{ }^{\circ} \mathrm{C} .{ }^{1} \mathrm{H}$ NMR $\left(500 \mathrm{MHz}, \mathrm{CDCl}_{3}\right): \delta=9.06$ (apparent triplet, $\left.J 1.0 \mathrm{~Hz}, 1 \mathrm{H}\right), 8.82-8.86(\mathrm{~m}, 5 \mathrm{H}), 8.68-8.67(\mathrm{~m}, 2 \mathrm{H}), 8.01(\mathrm{dd}, J$ 8.2, $1.3 \mathrm{~Hz}, 1 \mathrm{H}), 7.90-7.92(\mathrm{~m}, 4 \mathrm{H}), 7.47(\mathrm{~d}, J 4.6 \mathrm{~Hz}, 2 \mathrm{H}), 6.76(\mathrm{dd}, J 6.6,2.1 \mathrm{~Hz}, 2 \mathrm{H}), 5.31(\mathrm{dd}, J 6.6,1.1 \mathrm{~Hz}$, $1 \mathrm{H}), 1.08(\mathrm{~s}, 9 \mathrm{H}) \mathrm{ppm} .{ }^{13} \mathrm{C} \mathrm{NMR}\left(125 \mathrm{MHz}, \mathrm{CDCl}_{3}\right): \delta=152.65,152.61,151.88,151.84,150.39,150.36,150.10$, $150.01,143.87,132.56,131.37,131.35,131.33,131.16,131.13,130.80,130.37,130.30,130.29,130.18$, 130.16, 126.22, 125.87, 125.76, 123.32, 122.50, 122.39, 122.37, 117.83, 94.12, 89.04, 33.97, 31.45 ppm (2 signals missing). HRMS (ESP) calcd for $\mathrm{C}_{41} \mathrm{H}_{29} \mathrm{BN}_{7} \mathrm{O}^{+}\left[\mathrm{M}+\mathrm{H}^{+}\right]: m / z=646.2521$, exp: $m / z=646.2520$.

\section{Acknowledgements}

The Independent Research Fund Denmark | Natural Sciences (\#8021-00009B) is acknowledged for financial support. Prof. Jesper Bendix is thanked for solving the X-ray crystal structure.

\section{Supplementary Material}

NMR spectra, UV-Vis absorption spectra and electrochemical data.

\section{References}

1. Claessens, C. G.; González-Rodríguez, D.; Rodríguez-Morgade, M. S.; Medina, A.; Torres, T. Chem. Rev. 2014, 114, 2192-2277. https://doi.org/10.1021/cr400088w

2. Meller, A. Ossko, A. Monatsh. Chem. 1972, 103, 150-155. https://doi.org/10.1007/BF00912939

3. Guilleme, J.; González-Rodríguez, D.; Torres, T. Angew. Chem. Int. 2011, 50, 3506-3509. https://doi.org/10.1002/anie.201007240

4. Gotfredsen, H.; Storm, F. E.; Muñoz, A. V.; Santella, M.; Kadziola, A.; Hammerich, O.; Mikkelsen, K. V.; Nielsen, M. B. Chem. Eur. J. 2017, 23, 16194-16198.

https://doi.org/10.1002/chem.201704551

5. Gotfredsen, H.; Jevric, M.; Broman, S. L.; Petersen, A. U.; Nielsen, M. B. J. Org. Chem. 2016, 81, 1-5. https://doi.org/10.1021/acs.joc.5b02719

6. Helander, M. G.; Morse, G. E.; Qiu, J.; Castrucci, J. S.; Bender, T. P.; Lu, Z-H. ACS Appl. Mater. Interfaces 2010, 2, 3147-3152.

https://doi.org/10.1021/am100632y

7. Sullivan, P.; Duraud, A.; Hancox, I.; Beaumont, N.; Mirri, G.; Tucker, J. H. R.; Hatton, R. A.; Shipman, M.; Jones, T. S. Adv. Energy Mater. 2011, 1, 352-355.

https://doi.org/10.1002/aenm.201100036

8. Beaumont, N.; Cho, S. W.; Sullivan, P.; Newby, D.; Smith, K. E.; Jones, T. S. Adv. Funct. Mater. 2012, 22, 561-566. 
9. Pandey, R.; Zou, Y.; Holmes, R. J. Appl. Phys. Lett. 2012, 101, 033308. https://doi.org/10.1063/1.4737902

10. Beaumont, N.; Castrucci, J. S.; Sullivan, P.; Morse, G. E.; Paton, A. S.; Lu, Z-H.; Bender, T. P.; Jones, S. J. Phys. Chem. C 2014, 118, 14813-14823. https://doi.org/10.1021/ip503578g

11. Cnops, K.; Cheyns, B. P. R, D.; Verreet, B.; Empl, M. A.; Heremans, P. Nat. Commun. 2014, 5:3406. https://doi.org/10.1038/ncomms4406

12. Castrucci, J. S.; Josey, D. S.; Thibau, E.; Lu, Z-H.; Bender, T. P. J. Phys. Chem. Lett. 2015, 6, 3121-3125. https://doi.org/10.1021/acs.jpclett.5b01254

13. Duan, C.; Zango, G.; Iglesias, M. G.; Colberts, F. J. M.; Wienk, M. M.; Martínez-Díaz, M. V.; Janssen, R. A. J.; Torres, T. Angew. Chem. Int. Ed. 2017, 56, 148-152. https://doi.org/10.1002/anie.201608644

14. Xu, H.; Jiang, X.-J.; Chan, E. Y. M.; Fong, W.-P.; Ng, D. K. P. Org. Biomol. Chem. 2007, 5, 3987-3992. https://doi.org/10.1039/B712788J

15. Spesia, M. B.; Durantini, E. N. Dyes Pigm. 2008, 77, 229-237. https://doi.org/10.1016/i.dyepig.2007.05.008

16. Gotfredsen, H.; Neumann, T.; Storm, F. E.; Muñoz, A. V.; Jevric, M.; Hammerich, O.; Mikkelsen, K. V.; Freitag, M.; Boschloo, G.; Nielsen, M. B. ChemPhotoChem 2018, 2, 976-985. https://doi.org/10.1002/cptc.201800135

17. Gotfredsen, H.; Jevric, M.; Kadziola, A.; Nielsen, M. B. Eur. J. Org. Chem. 2016, 17-21. https://doi.org/10.1002/ejoc.201501264

18. Gotfredsen, H.; Broløs, L.; Holmstrøm, T.; Sørensen, J.; Muñoz, A. V.; Kilde, M. D.; Skov, A. B.; Santella, M.; Hammerich, O.; Nielsen, M. B. Org. Biomol. Chem. 2017, 15, 9809-9823. https://doi.org/10.1039/C7OB01907F

19. Wrackmeyer, B. Progress in NMR spectroscopy 1979, 12, 227-259. https://doi.org/10.1016/0079-6565(79)80003-5

20. Muñoz, A. V.; Gotfredsen, H.; Jevric, M.; Kadziola, A.; Hammerich, O.; Nielsen, M. B. J. Org. Chem. 2018, 83, 2227-2234.

https://doi.org/10.1021/acs.joc.7b03122

21. Bukuroshi, E.; Petersen, A. U.; Broløs, L.; Bender, T. P.; Nielsen, M. B. Eur. J. Inorg. Chem., in press. https://doi.org/10.1002/ejic.202000525 